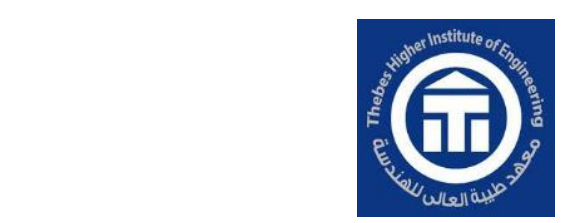

INTERNATIONAL JOURNAL OF ADVANCED ENGINEERING

AND BUSINESS SCIENCES (IJAEBS)

Journal homepage: International Journal of Advanced Engineering and Business Sciences (ekb.eg)

\title{
The Identity of Contemporary Egyptian Architecture
}

\author{
Mohamed Adel Salama \\ Architectural Engineering department, Thebes higher institute for Engineering.
}

*Corresponding author: Email address: mas_siak@yahoo.com

Received: 19 September 2021 Accepted:25 September 2021 Published:26 September 2021

\begin{abstract}
The research aims to find an Egyptian local architectural identity which has cultural, climatic and environmental relations with this society. Therefore, the research identifies and analyzes the types of the contemporary Egyptian architecture by dividing it into two directions.

The first directions is the architecture that comes from the Egyptian environment such as reviving the old historical Architectural heritage by inspiring ideas and vocabularies from the Egyptian architectural heritage by reviving the Pharaoh style or different Islamic architectural styles, Also, many trials had appeared to go toward the local architecture which is connected to the local places and environment in order to conserve the local culture and to create a local architectural style by inspiring the local inherited architecture and taking from its vocabulary and symbols forms.

The second direction is to go towards the western thoughts that depend on the western architecture as it is the source of the modern architectural thoughts, and also to benefit from the modern techniques and potentials in order to achieve the continuity between the past and the present. Also, there were some individual trials resulted an uncommon architecture depended on the personal potential of the architect himself to take out the architectural work from the common and to express a thing in his mind that represented a kind of thoughts privacy, then the non-local architecture

The research resulted that designing trials must be done to establish Egyptian architectural style match with our culture and our environment and comes from our local environment.
\end{abstract}

KEYWORDS: Architectural Identity, Environmental Architecture, Egyptian Architecture styles, Western Architecture

International Journal of Advanced Engineering and Business Sciences, Volume 2, Issue 2, September 2021 - ISSN 2682-2938 Innovation and Research Center, Faculty of Engineering and Management Science, Integrated Thebes Academy (ITA). 


\section{المعاصرة المصرية للعمارة الهوية}

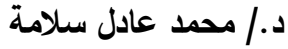

قسم الهنسة المعمارية, معهد طيبة العالى للهندة ,المعادى, القاهرة

الملخص

يهذف البحث الى إيجاد هوية معمارية مصرية محلية ذات علاقة ثقافية مناخيه بيئيه لهذا الهتمع, و عليه يقوم البحث بالتعرف على أنماط العمارة المصرية المعاصرة وبتحليلها و ذلك بتقسيمها الى اتجاهين.

من التراث القديم باستلهام أفكار أو مفردات التاريخى المعمارى التراث الاتجاه الأول هو العمارة النابعة من البيئية المصرية مثل إحياء المختلفة, و كذلك التوجه نحو العمارة المحلية, التى ترتبط الإسلامية المعمارية الطرز أو الفرعونى الطراز المعماري المصري وذلك بإحياء المحلى والإقتباس العمران موروثات إستلهام طريق عن عمرانى محلى طابع وخلق المحلية الثقافة على المحافظة بالمكان و البيئة المحلية, بهدف وأشكال رموزه. مفراداته من

للفكر مصدرا العمارة الغربية باعتبارها على الاتجاه الثانى هو العمارة ذات الاتجاه العالمى مثل التوجه نحو الفكر الغربى الذى يعتد الماضى و الحاضر , بالاضافة الى توجهات معمارية بين لتحقيق التواصل المعاصرة و الامكانات التقنيات من الاستفادة مع المعاصر المعماري أخرى النابعة من المحاولات الفردية نتج عنها عمارة غير مألوفة تعتمد على القدرات الثخصية للمعمارى للخروج بالعمل المعمارى عن المألوف محلية. الغير و التعبير عن شئ فى ذهنه و يمثل نوع من الخصوصية الفكرية, ثم العمارة

محاولات تصميمية لتأسيس طابع معماري مصري يتتاسب مع ثقافتنا و بيئتنا نابع من البيئة وجود على العمل و قد خلص البحث أنه يجب المحلية.

الكلمات المفتاحية: الهوية المعمارية, العمارة البيئية, أنماط العمارة المصرية, العمارة الغربية 


\section{INTRODUCTION}

The importance of architecture resides in highlighting society's identity. Consequently, architectural identity is defined as architectural distinction and uniqueness of a society. This is because architectural identity expresses society cultural identity and is considered the principal criterion for measuring how successful architecture is in a society [4], consequently, architectural identity is the distinction and uniqueness of a given society. This uniqueness arises from the political, economic, environmental, social and cultural factors surrounding this society [16]. Architectural identity is expressed in the form of buildings and the architectural decorations since each building is related to the values which the building and its users basically express [10].

Architectural identity is a lively and honest expression of society culture. It is the honest translation of society in its material and spiritual aspects. I is also a constant reminder and a link which connect major periods of development in the culture of national characters [11].

\section{RESEARCH PROBLEM}

Egypt lives in a random period in architecture where all architectural styles are built without any coordination without any architectural style. If we look at contemporary Egyptian architecture, we notice that certain architectural forms which are affected by western architectural types, these types showed that Egyptian architecture is a mixture of disharmonies types. Some types are affected by architectural heritage, other types are transmitted from western architecture which raided and influenced the architectural scene.

Consequently, Egyptian architecture lost its identity through losing its components arising from local values which express national, social and even climatic environment.

This research is an attempt to find local Egyptian architectural identity with environmental, cultural and climatic relationship with the Egyptian society.

\section{RESEARCH OBJECTIVE}

The research is an attempt to recognize if the contemporary Egyptian architecture has a definite identity which differentiates it from other types of identity, with an emphasis on its local identity which has definite features and does not follow international architectures. 


\section{RESEARCH IMPORTANCE}

Peoples of the world, since the beginning of humanity until the present, have been keen on conserving their uniqueness, socially, nationally and culturally. Accordingly they were keen to have an identity that would help promoted the people status in societies.

Hence the importance of architectural identity comes from expressing society's culture since it is considered a reflection of society nature and traditions in all their social, psychological, economic, political and historical aspects. Architecture is the mirror which reflects people's culture, revival and development, therefore connecting architecture with society helps in finding the civilized form for architecture, in which contemporary is connected with authenticity.

Egyptian architecture, then, should reflect the Egyptian society in a way that provides for its civilized values continuity of heritage and local characters.

\section{METHODOLOGY}

The research follows the analytical methodology which explains and analyzes the architectural types present in Egyptian architecture to find a local Egyptian architecture that has environmental, climatic and cultural relationship with this society as follows:

1- Architecture arising from the Egyptian environment such as reviving historical ancient architectural heritage, going towards local architecture.

2- Architecture having the international direction such as go towards the western thoughts, other architectural trends and non-local architecture.

\subsection{ARCHITECTURE ARISING FROM THE EGYPTIAN ENVIRONMENT}

\subsubsection{Revival to ancient historical architecture}

In this orientation, it is found that contemporary Egyptian architecture is an inspiration vocabularies or thoughts from Egyptian historical heritage. The process of reviving or inspiring from architectural heritage in Egypt started by borrow ant inspire from the civilized ancient origins through reviving the Pharaohs style or different Islamic architectural styles in their different periods by using forms and vocabularies of these styles in designing public and institutional buildings as a direct expression of the specialty of country's cultural and civilized identity [6].

Revival of historical styles was done by either through direct copying and imitating parts of or whole the ancient heritage buildings or borrowing features from the vocabularies of these buildings, 
such as the shape of the openings or ornamental details and cornices and complying them in architectural forms and designs different from their old origins. This orientation had diverted by the time from its original motives and changed into a demonstration of luxury and prestige which in turn developed into a mixture of buildings which lack of good artistic taste due to the fact that most of who are practicing lack of architectural culture and good knowledge of the origins and philosophy of historical architectural styles [6].

\subsubsection{Inspiring by heritage Pharaohs style}

In the beginning of the Twentieth century, some architects tended to use forming features of Pharaohs style such as gates, columns and cornices in public buildings, examples of these buildings are Saad Zaghlool mausoleum, Luxor railway station (Figure 1) and Giza railway station (Figure 2) and many other public and religious building outside an inside Egypt [9].

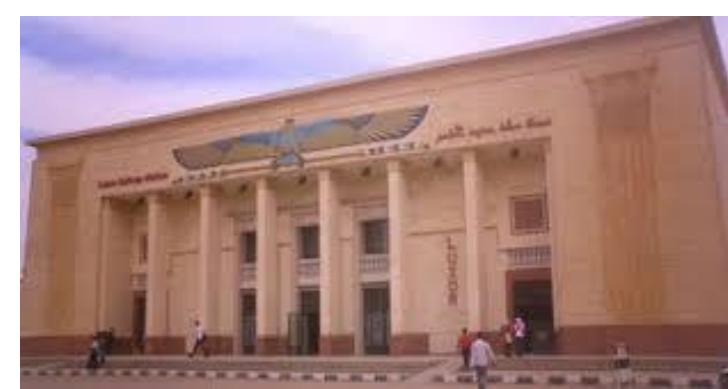

Figure (1): Luxor railway station

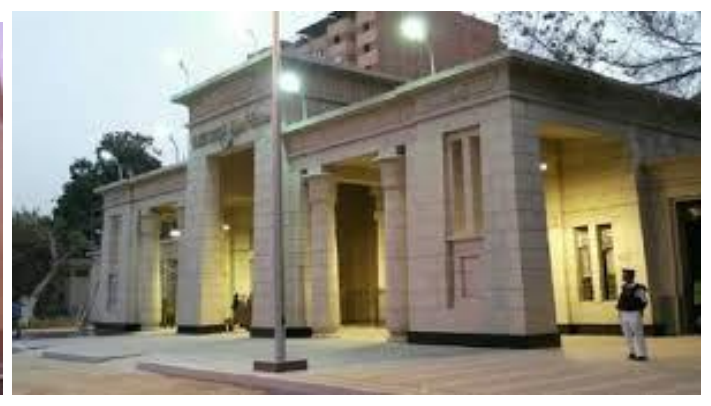

Figure (2): Giza railway station

By studying Saad Zaghlool mausoleum which was built in 1927, it was found that it was built according to Pharaohs style where Pharaoh vocabularies were used such as huge Pharaohs columns made of granite and the huge cornice that tower the building, in addition to vertical openings which are placed in the middle the stone block. The mausoleum is surrounded by a garden from the four directions and a steel fence with brass lotus flowers surrounds it. The garden has twelve basalt flower pots taking the shape of lotus flower. Moreover, red granite was used in the two main entrances as each entrance has two Pharaohs style, columns made from red granite. In addition, ornamental elements were successfully used such as winged sun disk, Hathour face, lotus flower and papyrus. They were well located and merged in harmony in such a way which Indicates an understanding of ancient Egyptian architecture, also the architect succeeded with his cleverness and deep understanding of ancient Egyptian civilization tp comply all these $\mathrm{d}$ ornamental elements and building materials to produce a modern update building as shown in Figure (3) [17] 


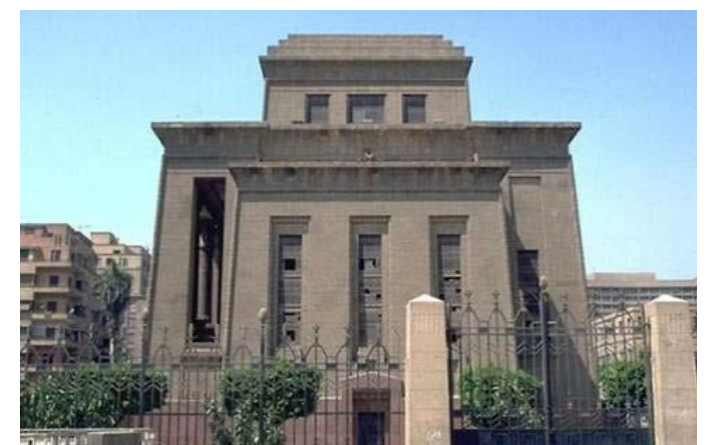

Figure (3): Saad Zaghlool mausoleum

In the 1900 's of the $20^{\text {th }}$ century, it is found another return to inspire from the Pharaohs style in design through two main directions. The first direction is an extension of that which appeared in the beginnings of the $20^{\text {th }}$ century which depended on transferring vocabularies of the Pharaohs temples to buildings façade such as supreme constitution court building [5].

By studying supreme constitution court building which was opened in 2001, it was found that it was built in the style of Luxer temple on 14 Pharaohs obelisks at the ground floor and 14 obelisks from the first floor to the fourth floor. It was considered to benefit from the design of the Egyptian temples, columns, crowns which were adorned with lotus flowers and papyrus. The columns were 28 meters high. A fountain shaped like lotus flower was also built [18]. The designer has used the Pharaohs style in designing the facades by using Pharaohs vocabularies. Also the walls of the building look like ancient Egyptian walls as they were built to be thick at the bottom and go thinner gradually as it goes high. So, it was found that orientation of the architect in designing this building was towards Pharaohs architecture in an attempt to achieve Egyptian identity through it. Therefore, he imitated ancient Egyptian temples in their design through greatness, texture, color and use vocabularies and elements of Pharaohs architecture and its forms (Figure 4) [3].

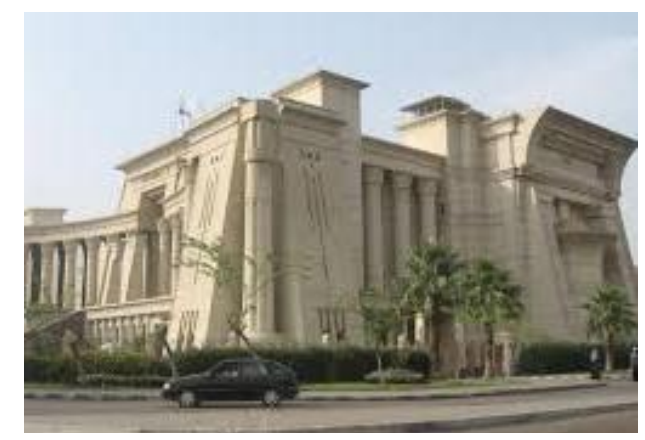

Figure (4): supreme constitution court building

The second orientation stressed on the use of the pyramid form which was strongly related to Pharaohs pyramids such as City of Scientific Researches and Technological Applications at Bourg 
Alarab, Sharm Al-Skiekh international hospital (Figure 5) and the main building of Pharaohs Sonesta hotel at Herghada (Figure 6)
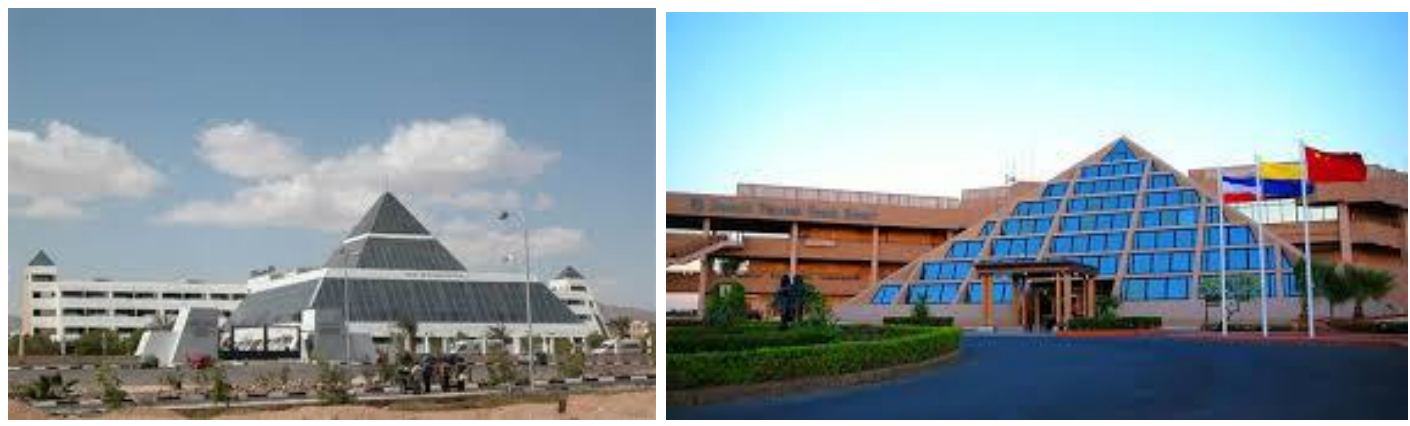

Figure 5: Sharm Al-Skiekh international hospital Figure 6: Pharaohs Sonesta hotel

By studying the City of Scientific Researches and Technological Applications which was opened in 200o, it was found that Research Institutes were designed in the form of three pyramids, the plan of each one is square in its center there is a patio covered partly with the two pyramids sides and the other half is covered with a half dome. (Figure 7) [9].

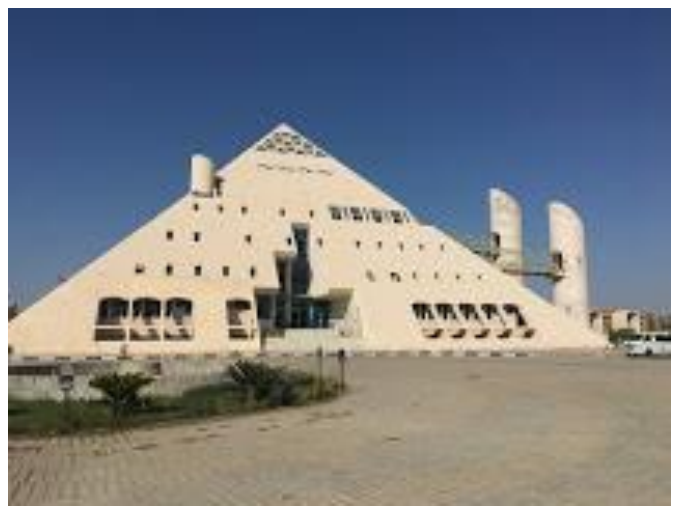

Figure 7: City of Scientific Researches and Technological Applications

\subsubsection{Inspiring from heritage Islamic architecture}

Inspiring from heritage Islamic architecture started in some buildings in the first half of the $20^{\text {th }}$ century such as the high institute of Arabic music building and the building of Egyptian Engineers society (Figure 8), as their designers inspire some vocabularies and elements from Islamic style in their designs [9]. 


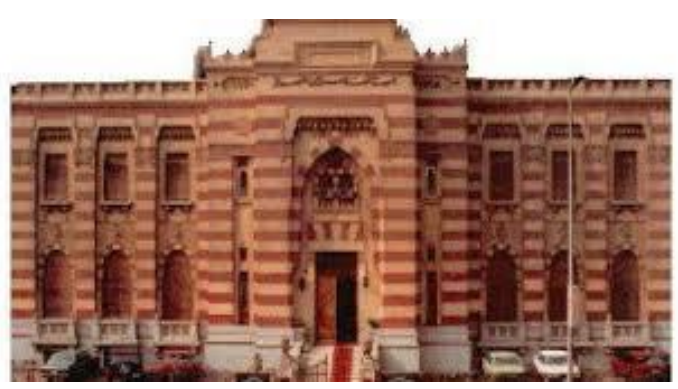

Figure 8: Egyptian Engineers society

By studying the high institute of Arabic music building which was built in 1923, it was found that it is characterized with Islamic architectural vocabularies which are represented in the huge pointed arch that confirms the main entrance and the wooden mashrabiyyas which are located in the building facades, in addition to the high dome that is decorated with Islamic decorations (Figure 9) [20].

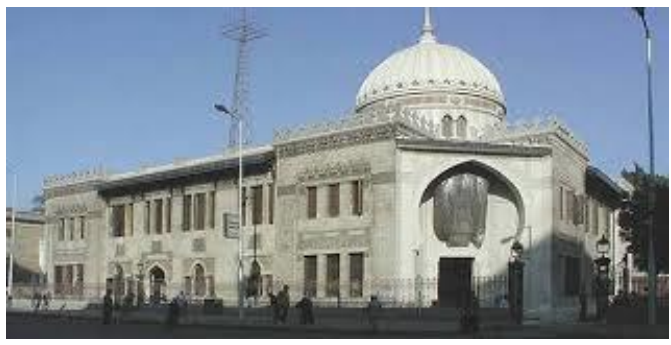

Figure 9: the high institute of Arabic music building

In the eighties and nineties of the past century started to appear models of buildings where revival of Islamic architectural thoughts appeared once again. They inspired the sprit and vocabularies from Islamic architecture in their designs. Gleaning from heritage means borrow vocabularies, forms, and spaces relationships from the heritage and attempt to formulate them within the contemporary architectural product. These models were concentrated in two main projects, first one are the residential and administration buildings and the other are projects which have tourists function [4]. Some of the models that were considered as honest attempts to produce contemporary architecture bringing their origin from Islamic heritage are Planning and Architectural Studies Center which consists of two parts around a patio which is widen in the upper floors with projections of building facades from outside. This is in addition to use mashrabiyyas in building facades to increase privacy as shown in Figure (10) [20], Al-Azhar Sheikhdom building, Egyptian Dar El-Effta building (Figure 11) and world trade center on Nile cornice [9]. 

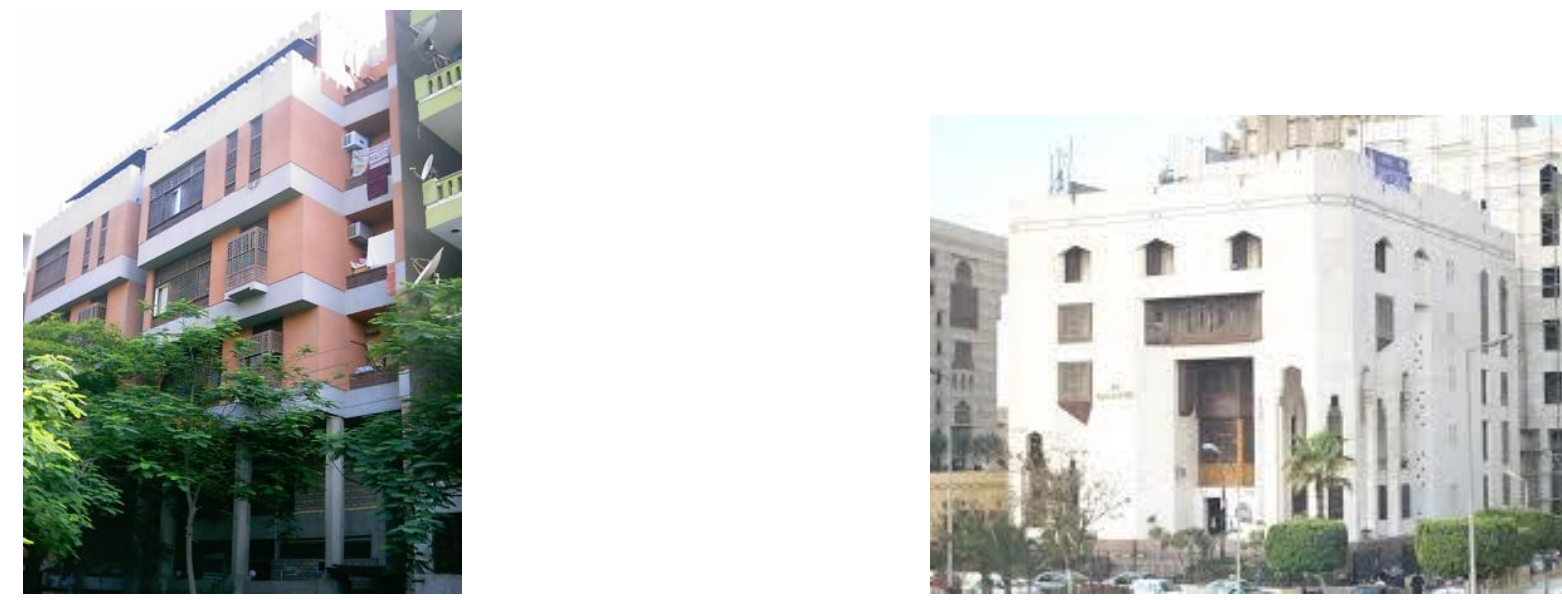

Figure (10): Planning and Architectural Studies Center Figure 11: Egyptian Dar El-Effta

By studying the Al-Azhar Sheikhdom building which is built in 1990. it was found that the idea of the building succeeded in achieving harmony and integration between the building and the architectural and its surrounding area characteristics that have Islamic features, as long with the building integration with The neighbor buildings such as Egyptian Dar El-Effta building. In addition, using luxury in the design of the facades and using an octagonal design unit in designing the grand Imam office in perpendicular and diagonal axis, and using the idea of the Islamic mashrabiyya and the developed decorations which express the sprit of the era without prejudice to the essence of its vocabularies and using Al Azhar mosque vocabularies in forming the building especially the architectural forms of the grand imam office (Figure 12) [19].

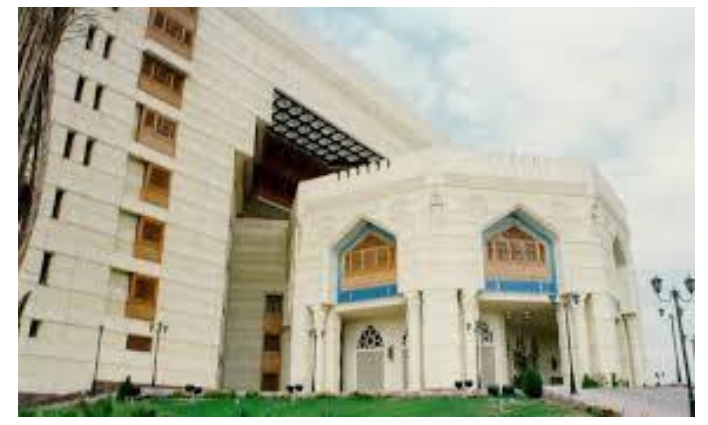

Figure 12: Al-Azhar Sheikhdom building

Also by studying the towers of the World Trade Center on Nile cornice, it was found that the architect had added a group of Islamic vocabularies to the façade such as the mashrabiyya, Islamic forms and the use of designs which were inspired from Islamic ornaments in the internal walls in the an attempt to be compatible with Islamic architecture[20]. By this, It was confirmed that the orientation of inspiring from Islamic vocabularies and elements commensurate with high buildings. 
This gives a clear prove for the possibility of benefiting from Islamic heritage in the contemporary architecture which concentrate on using high buildings (Figure 13) [9].

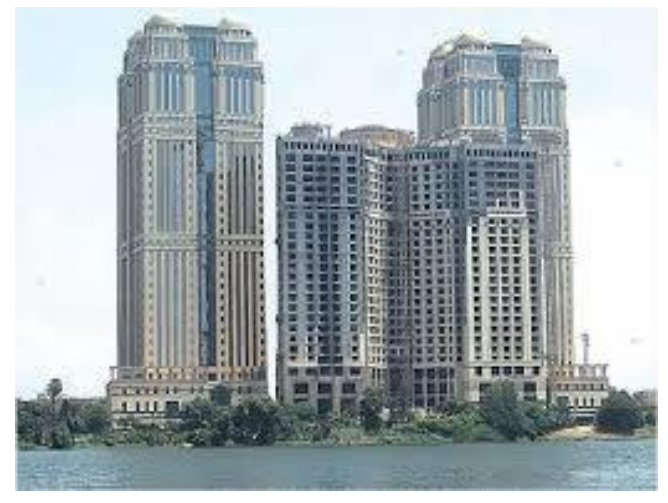

Figure 13: the towers of the World Trade Center

\subsubsection{Integration between heritage and contemporary}

Architects try to integrate between the ancient and the modern, i.e. integrate between originality which is represented in heritage and contemporary which is represented in the spirit of modernism period in which the world lives and coexists according to its principles. And this is through understanding the meaning of heritage and contemporary, analyzing constants of architectural heritage, trying to find an architectural language which is derived from it and connected with concepts of contemporary and modernism [5] and trying to reform architectural vocabularies which were borrowed previously from heritage to form another type of contemporary architecture [7]. This direction has developed by many architects and the direction towards inspiring from heritage did not become direct coping and borrowing forms and symbols and recopy them. Also borrowing from the language and vocabularies of local elements and reforming them on order to establish modern architecture which express society's specialty and culture, and have the dynamics and spirit of the era and use its tools[6]. The most important buildings in which appear this direction is Enpy company building, Art Palace building "Nile Hall previously" (Figure 14), AUC student's hostel and the children park at Sayyeda Zeineab in which the spiral shape of the minaret of Ibn Tolon mosque was used (Figure 15) [7]. 


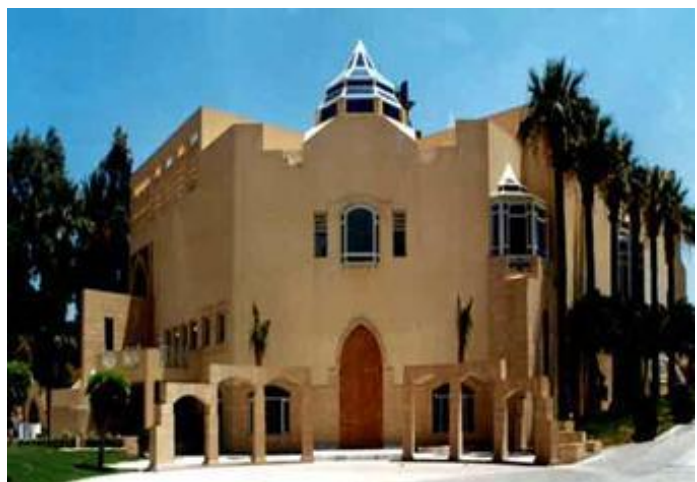

Figure 14: Art Palace building

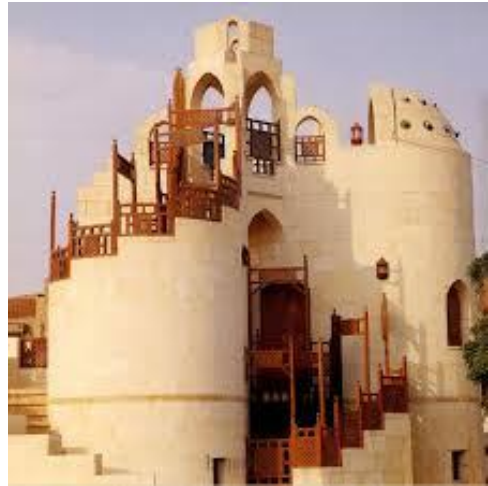

Figure 15: the children park

By studying AUC student's hostel, it was found that it express the Islamic heritage through privacy and opening towards inside and using heritage vocabularies in the façade such as the mashrabiyya, arches, decorations and cornices. Moreover the architects took attention to the concept of neighborhood by making an internal patio surrounded by different building spaces (Figure 16) [ 20].

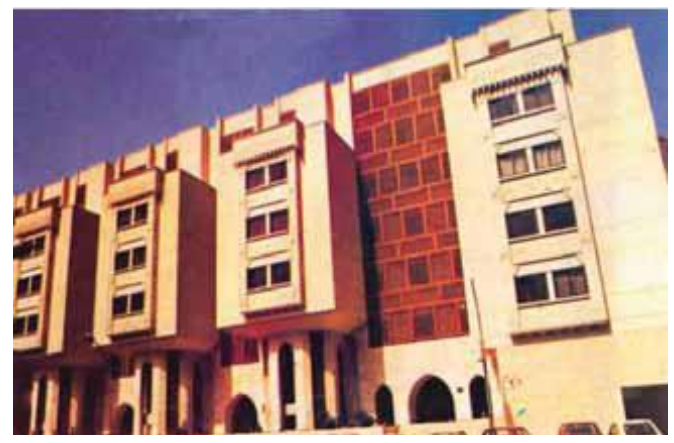

Figure 16: AUC student's hostel

Also by studying Enpy Company building, it was found that the architect applied western principles in designing the form of the building as this form foes not belong to the local Egyptian environment, but he had borrowed some Islamic vocabularies in the internal shapes such as the Islamic fountain and columns module which inspires Pharaohs columns foyer and symmetrical of the building around one axis like Pharaohs architecture (Figure 17) [20].

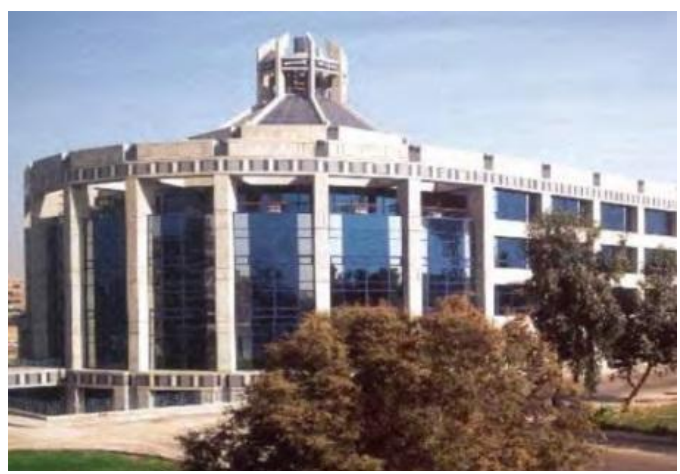

Figure 17: Enpy Company building 


\subsubsection{Orientation towards local architecture}

This orientation is connected to the place and its heritage givens, as it is connected to locality as a source of thought with its forms and symbols which are connected with place, society and environment [1].

\subsubsection{Inspiring from the heritage of popular architecture}

Movements of reviving popular heritage were developed to an direction aims to conserve the local culture and create local urban style by inspiring the heritage of popular architecture and borrowing from its vocabularies, forms and symbols to make roots of this direction and achieve architectural types which express the local culture and environment. One of the most important pioneers of this direction is the architect Hassan Fathy who advanced this direction as an environmental architectural type with local cultural urban style and revived methods of design and local construction especially of Nuba old architecture. One of his important work was the design of AL-Korna village in Upper Egypt (Figure 18) [6].

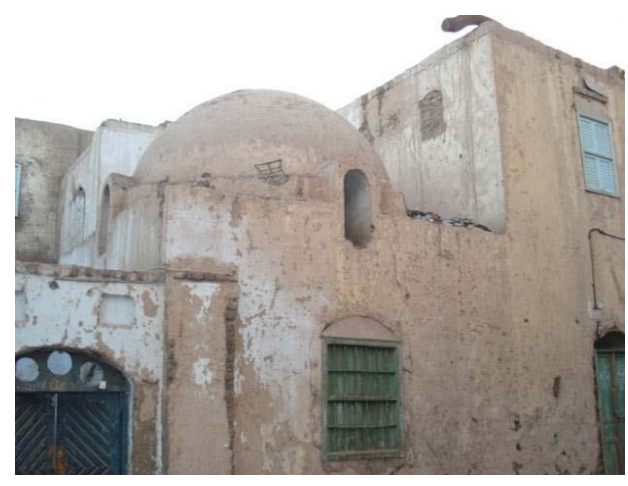

Figure 18: AL-Korna village

\subsubsection{Inspiring from the heritage of local architecture}

This direction appeared in the eighty's and the ninety's of the $20^{\text {th }}$ century in many of architectural works which was concentrated on residential buildings and palaces in Cairo suburbs at Harrania and Badrasheen and elsewhere. Besides this direction was used in constructing many tourist resorts and villages in the same style which depends using load bearing stone or brick walls and vaults and domes in roofs [9]. One of the important buildings that show this direction is the village of journalists on the north coast (Figure 19), the international center of craft (Figure 20) and Kafr ElGouna village in Herghada [5]. 


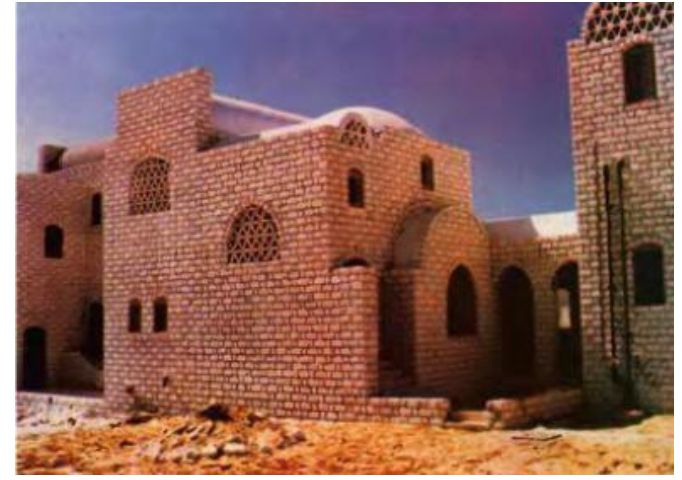

Figure 19: village of journalists

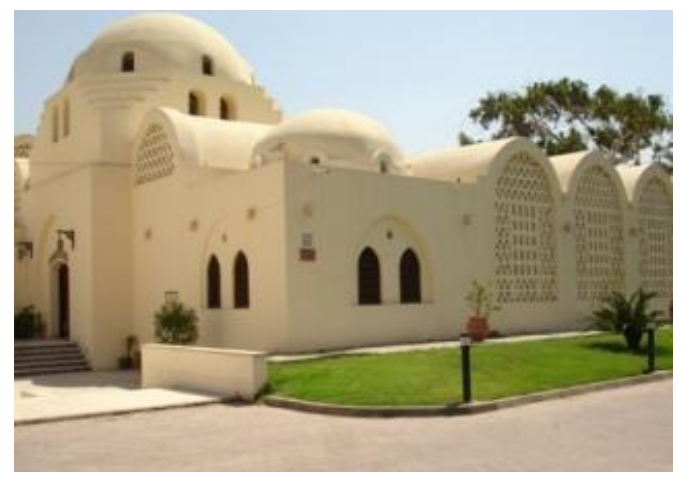

Figure 20: the international center of craft

By studying Kafr El-Gouna village in Heghada, it was found that the forms vocabularies which were used were derived from the environment such as small openings, domes and vaults. Early signs of this project were appeared in 1992 when there was a need to construct a residential compound for a group of employees which were working in the tourist hotels in the region. The idea of the project was to find a compound for these employees that matches with the surrounding environment and able to concern the importance of this tourist region away from the typical units which have negative effect on their residents, load bearing walls were used (Figure 21) [20].

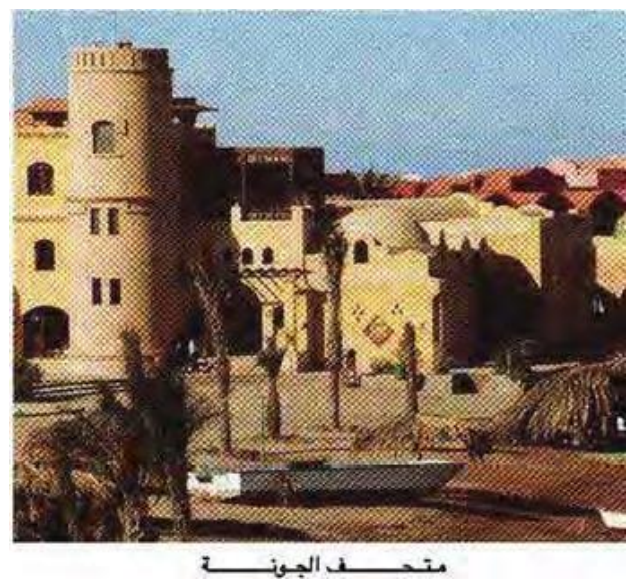

Figure 21: Kafr El-Gouna village

\subsubsection{The Authenticity direction in architecture}

It is the continuation of the attempts of the architects Hassan Fathy, Ramsis Wissa Wasif and the architects who learned from them to revive local architecture and emphasis on the importance of employing technology that matches with suitable building material in order to be sure that the architectural work includes a rich language which can tough the users conscience and expresses his 
environment. One of the most important buildings which show this direction is Paris village in the New Valley (Figure 22) and the museum of Nuba monuments building in Aswan [5].

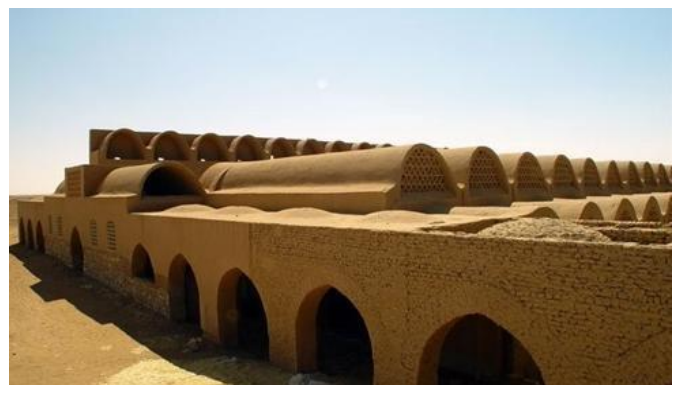

Figure 22: Paris village in the New Valley

By studying the museum of Nuba monuments building in Aswan, it was found that it contains eight main areas which are the entrance, the external display, the cave, the Nubian village, the open theatre, display of big monuments and Islamic monuments. The architect tried to achieve integration with the surrounding environment through matching with the contour lines and designing a low building with imbricate blocks to maintain the sky line and provide great amount of shades, as well as using Nubian architectural vocabularies in treating the windows and entrances such as Nubian arch and parapet decorations. In addition to using solid external walls (Figure 23) [20].

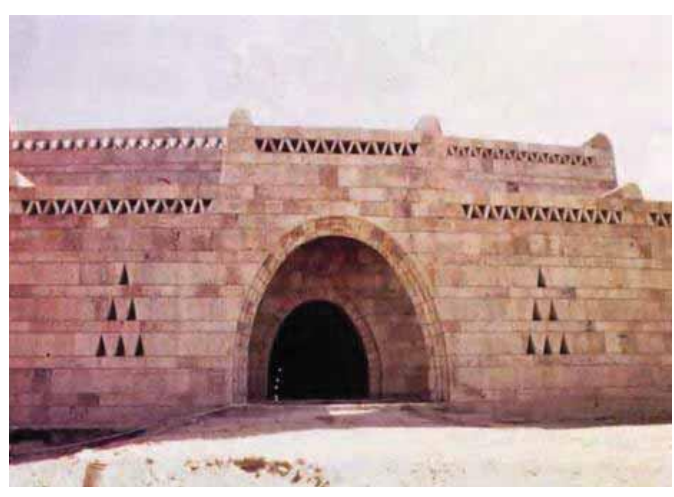

Figure 23: the museum of Nuba monuments building

Accordingly, the Architecture which arises from the Egyptian environment appears in a good matter because Egypt has a distinguished architectural heritage that deals with local construction materials and human circumstances. This type emphasis on the local identity and the tools of this style is to use the same of old traditional systems and materials. Moreover, the revival of Islamic style depended on the principle of simplifying the Islamic style and its ornaments and copying from the architectural decorations without going deeply in understanding the essence of architecture, consequently this direction lost his identity. 


\subsection{UNIVERSAL DIRECTION ARCHITECTURE}

\subsubsection{Orientation towards western thought}

This orientation depends on western architecture as a reference and a source for architectural thoughts and design visions, as this direction is considered matching with modern architecture and post modern architecture in western world, and is considered as a source of modern architectural forms as long with benefiting of the modern potentials and techniques to achieve connecting between past and present [5].

\subsubsection{Modern architecture}

This direction appeared in the begging of $20^{\text {th }}$ century by changing gradually towards modern architecture, removing the control of Egyptian heritage, opening towards the outer world and matching the spirit of the era and technology and development. Modern architecture had spread in Egypt withal its principles whish called according to universal modernism such as seeking for idealism, making simplicity as expression of modern era spirit, maximum benefit of technological development, considering function is the most important in designing process, using simple clear forms and expanded horizontal lines and glazed and concrete areas, and fully canceling of decorations. The most important building of this period is Akhbar Alyoum building [5] as this building is considered one of the important buildings that dates the modern architecture in Egypt. In this building evaporate the features through the clear horizontal lines, the typicality, and using simple architectural vocabularies such as straight glazed windows (Figure 24) [20].

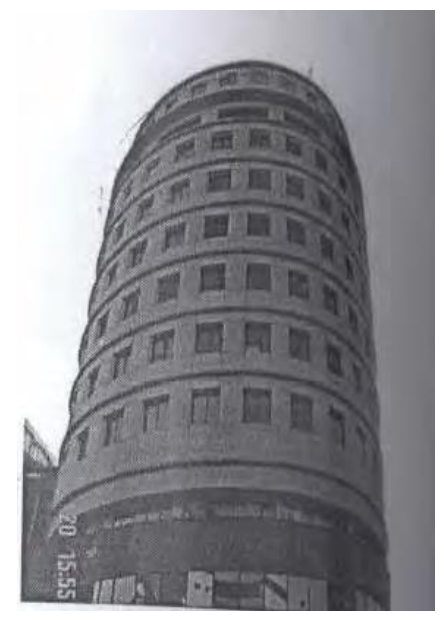

Figure 24: Akhbar Alyoum building

In the middle of the 2oth century this direction has continued as a result of sending external delegations in architecture, from which architects has learned western architecture and when they 
returned became the heads of high education in Egypt and transferred what they had learned in the west to the academic movement in Egypt. One of the most important buildings in which this direction was appeared is Accountability State Authority building (Figure 25) Central Agency for Public Mobilization and Statistics building (Figure 26) [5] and Sheraton Cairo hotel building.

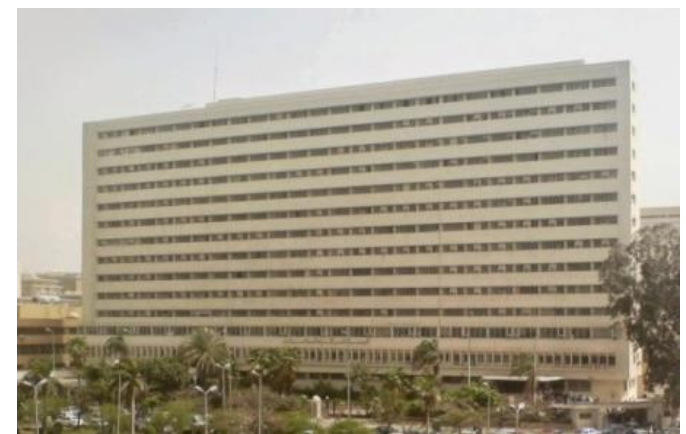

Figure 25: Accountability State Authority building

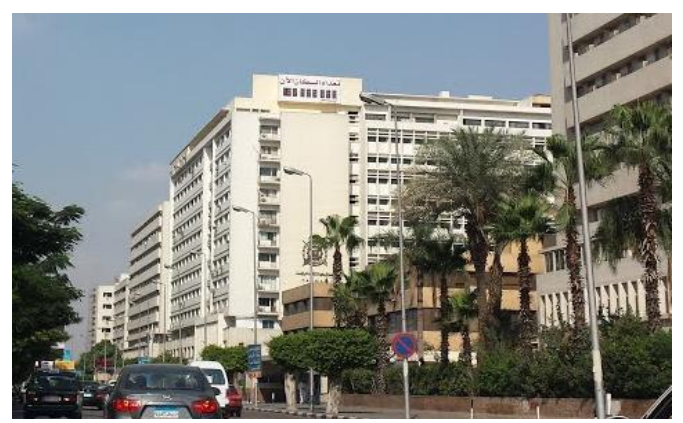

Figure 26: Public Mobilization and

Statistics building

By studying Sheraton Cairo hotel building, it was found that the building belongs to modern architecture through many feature such as emphasizing on the simple horizontal and vertical lines, emphasizing on simplicity of form and the emptiness of decorations in the building (Figure 27) [5].

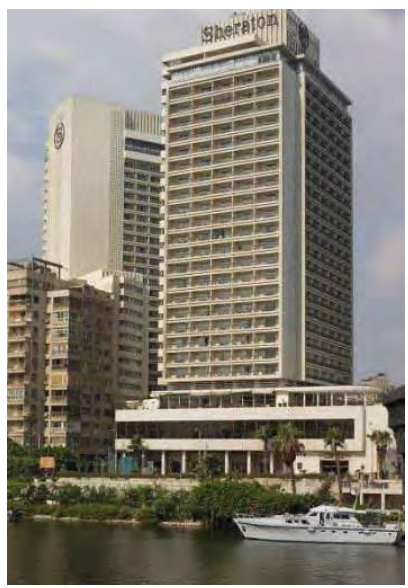

Figure 27: Sheraton Cairo hotel building

In the period between 1970 and 1980, using universal modern architectural orientations was still continued in Egyptian architecture despite that modern architecture was globally reviewed at that time about its principles [20]. The architectural facades of this orientation were used in the Egyptian architecture without considering its identity and culture which resulted of products do not belong to the society such as Om Kolsoum towers (Figure 28) [7] and Four season hotel (Figure 29). 


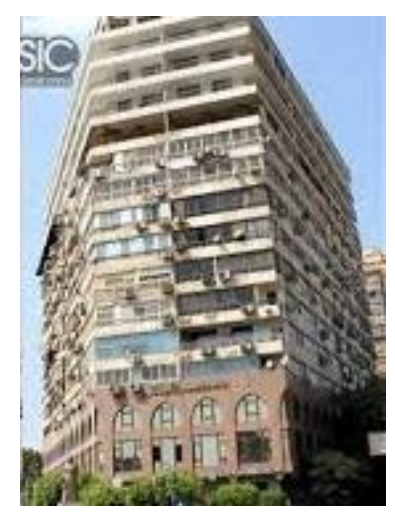

Figure 28: Om Kolsoum towers

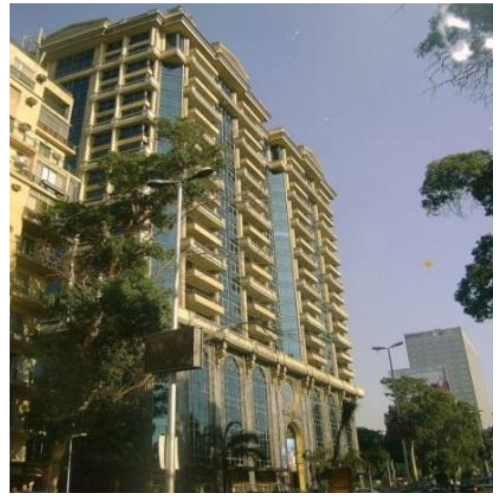

Figure 29: Four season hotel

\subsubsection{Western modern architecture}

This direction is called Egyptian - Foreign Dual, as in the latest of $20^{\text {th }}$ century, the foreign architect had returned to work another time, but with association with Egyptian architect which resulted architecture with no relations with the cultural contents or the Egyptian climate and its tradition, as this orientation was completely depending on western thoughts which look to architecture as an expression of technological development and not as a cultural construction has its own constant heritage [7]. This orientation was distinguished with modern western forming thoughts such as typicality, repetition, and the liberation of time and place hypotheses. This orientation had denied the effect of the Egyptian environment and its local identity. One of the most important buildings in which this orientation was appeared is Ramses Hilton hotel building, Semiramis Intercontinental hotel building (Figure 30) and Ministry of Foreign Affairs building (Figure 31) [5].

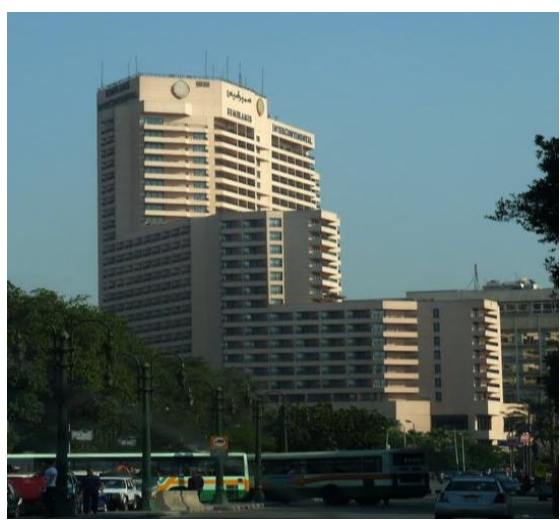

Figure 30: Semiramis Intercontinental hotel building

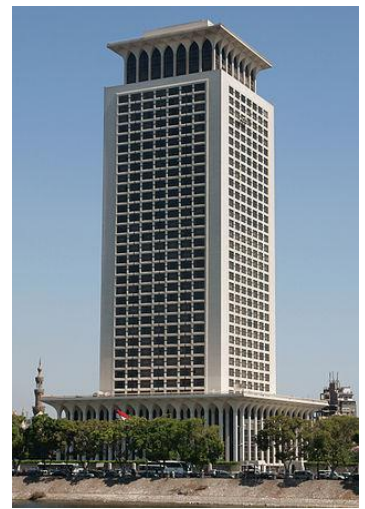

Figure 31: Ministry of Foreign

Affairs building

By studying Ramses Hilton hotel building, it was found that there is no an relationship between the building and its surrounding environment (Figure 32) [20] 


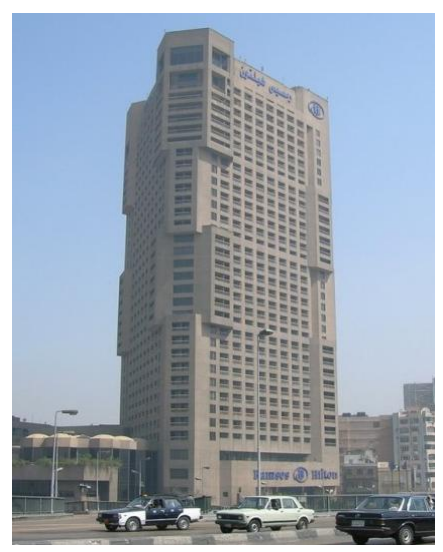

Figure 32: Ramses Hilton hotel building

\subsubsection{Another architectural orientation}

\subsubsection{Individual orientations produced non-common architecture}

This direction was depending on the personal potentials of the architect to exit the architectural work out of the common and express of something in his mind as it represents a sort of private thoughts [1]. This direction depends on the private vision of the architect through sculptural forms depend on the architect own reference and express his ability and cleverness and fulfill his desire of expression of himself and his distinguish among his colleagues. These orientations ignore the civilization features of the society. The buildings in which this orientation was appeared are Commercial Nile Center (Figure 33) and Dar AlTahrir institute building (Figure 34) [5].

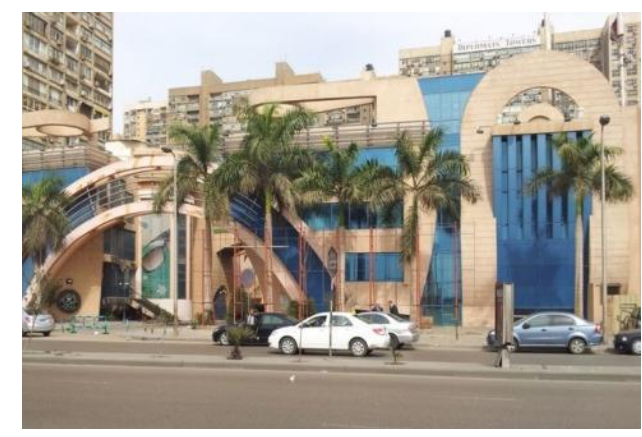

Figure 33: Commercial Nile Center

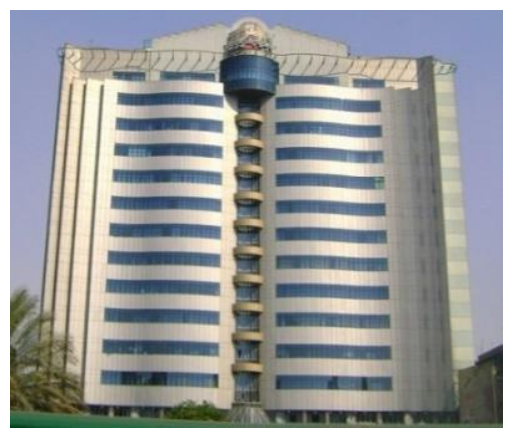

Figure 34: Dar AlTahrir institute building

\subsubsection{Non - Local architecture}

This style was appeared in the middle of $20^{\text {th }}$ century in the government buildings and suburb housing, and was copied from western models, or taken from different architectural styles. It was noticed in the government buildings that the political order wanted to construct government houses which were quickly designed and executed which resulted buildings in compact rows in all cities 
with repeated types did not suit the requirements of the surrounding environment because many construction systems which were borrowed from outside controlled their form, which resulted that these areas became forests of residential buildings (Figure 35) [4].

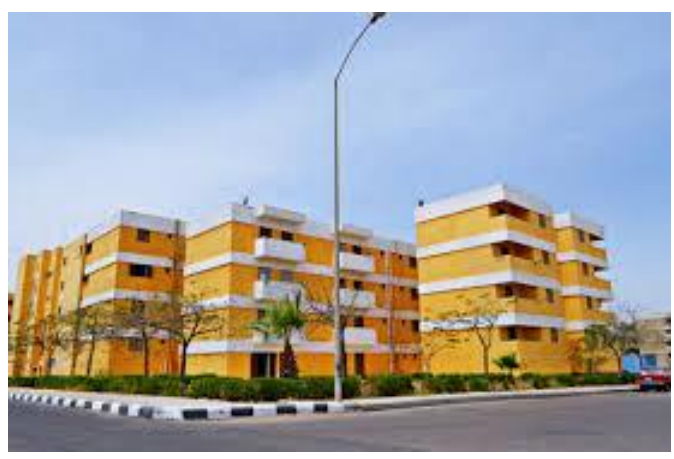

Figure 35: Sadat city

The architecture which follow the universal direction had used modern materials and construction methods and looked like as a repetition of the universal architecture and was designed for societies rather than the Egyptian society and traditions different than its traditions, therefore the buildings connected to an disassembled and opened urban pattern which did not express the human relationship, which resulted in social isolation, weakness in the bonds between people, losing of privacy inside and between buildings and boring repetition of building and did not connect with the surrounding environment. Therefore the Egyptian architecture lost its distinguished type and its identity.

\section{CONCLUSION}

Architectural heritage is the mirror which reflects the civilized identity for the human bean. The homogeneity between heritage and contemporary in the units that form the urban characteristics in any society is very important in order to appear as a one component connects between the changes and the historical development of this society.

Accordingly, it is found in Egypt random in architecture as all of the architectural styles are used without any coordination, architectural type and without determine an identity can be called Egyptian architecture, as the identity in the Egyptian architecture is lost between local and western architecture.

Also it is found that the contemporary Egyptian architecture had lost its identity and locality and is difficult to classify a clear direction express and distinguish the contemporary Egyptian architecture as it is distinguished with random architecture does not relate to the local environment 
such as the location, the climate, and is not suitable for the social requirements and the civilized values of the Egyptian society, because the universal architecture which depends on western architecture vocabularies and does not express the society culture and does not match with the local environment and does not have any relationship with heritage constants is dominated . Neglecting principles and standards of the traditional architecture resulted in the absence of distinguishing elements that elaborate the distinguished features of contemporary Egyptian architecture.

Therefore, it is a must to emphases on make contemporary design trials and establish an architectural Egyptian style which is suitable for the local culture an environment, and matches with the era development especially that Egypt has a lot of vocabularies that the Egyptian architecture owns them.

\section{REFERENCES}

$$
\text { 1- محمد ابراهيم جبر , 2003, "العمارة المصرية المعاصرة.. المعطيات و النتاج" }
$$

Assuit University - Second International Conference on 'Great Rivers as Attractors of Local

Civilization', October 2003 www.cpas-egypt.com > pdf > Mohamed_Gabr > Arb 2- مدحت درويش, "ثقافة المعماري و البحث عن الذات المصرية", ورقة بحثية, قسم العمارة, كلية الهندسة بشبرا, جامعة بنها www.cpas-egypt.com > pdf > Researches

3- غادة محمد السيد محمد شطا, 2016, " دور فن النحت في تحقيق الهوية للعمارة المصرية المعاصرة", كلية الفنون التطبيقية, جامعة staff.du.edu.eg > researches دمياط 4 - شريف محمد ربيع عبدالوهاب خشبه, هشام أحمد محمد صبح, إسلام رجب عبدالمجيد محمد خميس, 2017, "الهوية المحلية في تصميم مشروعات الإسكان المتميز بمصر , (نحو مدخل لتحسين استخدام المفردات المعمارية المحلية

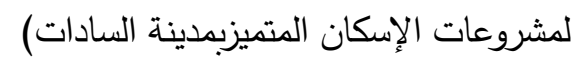

Journal of Al Azhar University Engineering Sector, Vol. 12, No. 43, April 2017 < jaes.journals.ekb.eg 5- عماد محمد محمد حسانين, هويدا سامى كمال محمد, محمد رمضان محمد أحمد, 2018, " رواد العمارة المصرية في النصف الثاني من القرن العشرين"

Journal of Al Azhar University Engineering ‘ jaes.journals.ekb.eg 6- عبدالرحمن عبدالنعيم عبداللطيف, 2012, "إستلهام التراث العمرانى - من الإستنساخ إلى تأصيل و إستدامة العمارة و العمران المحلى" Hosting Major International Events- Innovation, Creativity and Impact Assessment, Cairo, Egypt, December 22-25, 2012 scholar.cu.edu.eg > files > stlhm_ltrth_lmrny 
7- خلود حسن عبد اللطيف عزوز , " تأثير الهويـة والثقافة على سلوك الفرد داخل الفراغات الدعمارية", رسالة ماجستير , 2014, كلية الهندسة, جامعة القاهرة www.cpas-egypt.com > pdf > MS.c > 11- طــارق والـي, 2018. "الهويـة والإنسـان والعمـارة", محاضـرة عن تعريـف الهويـة وتأثيرهـا على العمـارة", قسم التصـيم الداخلي بكليه الفنون بجامعه اكتوبر للعلوم الحديثه والاداب, 22 نوفمبر 2048 2018, www.walycenter.org > 29-events > events > 404-hu 20- ايمان سامي عبد العليم عمارة, " أثر الثورات على المجتمعية على تطور الفكر المعمارى, (دراسة تأثر الحالة المعمارية فى مصر ثورة 25 يناير)", رسالة ماجستير , 2011, كلية الهندسة, جامعة حلوان www.cpas-egypt.com > pdf > Eman_Samy 5- عمر الحسيني عبد السلام, محمد تامر الخرازاتي. " تطور الفراغات العمرانية في مصر الجديدة ( النواة الأولى - واحة

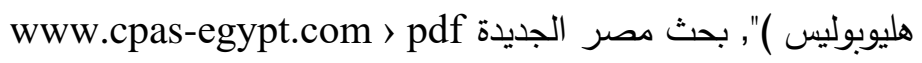

\section{ELECTRONIC SITES}

6- طراز عمارة هليوبوليس ( مصر الجديدة), 2009 yousefabdulsalam.blogspot.com > blog-post 7- العمارة المصرية المعاصرة - عالم نوح ( www.nouhworld.com > article 8- محمد مندور , 2018, "الهوية المعمارية معنية بتلبية حاجات المجتمع طبقا لمعتقداته وأفكاره" gate.ahram.org.eg > News 9- محمد الحمامصى, 2009, " القاهرة.. حلم الخديوي إسماعيل الذي لم يصنه المصريون" www.albayan.ae > WWW.pinterest.com > pin عمارة دى تربستا 10- محمد حسين, 2012, "هليوبوليس مصر الجديدة تحكي تراث مصر القديمة" helioegy.wordpress.com > 11- أريج كيوان, 2019, "هليوبوليس مدينة الثمس" < www.egyres.com 12- الهوية المعمارية تفاعل انساني وحضاري, 2015 www.almuraqeb-aliraqi.org 13 - شيماء الجرم,2017, "ضريح سعد باشا زغلول" www.misirkultur.net > 14- التصميم المعمارى Architecture \& Design, 2015 www.facebook.com > posts 15- جادالله فرحات, 2008, "مبنى مثيخة الأزهر الثريف" www.alraimedia.com > Home > Details

16- القاهرة الخديوية تصارع من أجل البقاء, 2019 www.france 24.com 